\title{
OR-79
}

\section{Antibacterial Activity of Ethanol Extract of Steam Bark of Cynometra Ramiflora Linn Against Various Bacterial}

\author{
Andi Suhendi, Peni Indrayudha, Haryoto, Tanti Azizah and Muhtadi
}

Faculty of Pharmacy, Muhammadiyah University of Surakarta, Jalan Achmad Yani, Tromol Pos 1, Pabelan, Kartasura, Surakarta 57102; Tel: +62271-717417

Cynometra ramiflora Linn traditionally used as anti diabetic, anti hyperuricemia, hypertension, rheumatoid, and others diseases. It is important to obtain other biological activity of Sala plant. Previous research found that the ethanol extract of the steam bark Sala plant from Bangladesh has antibacterial activity. The aim of this study is to evaluate the antibacterial activity of ethanolic extract of steam bark of Sala plant against five bacterial species based on value of MBC. Antibacterial evaluated by solid dilution method using Mueller Hinton (MH) media. The test divided to media control, solvent and bacteria suspension and the extract group. The extract screened against five bacteria (Shigella sonei, Pseudomonas aeruginosa, Klebsiella pneumoniae, Escherichia coli multi resistant and Staphylococcus aureus multi resistant) at four different concentration (0.125; $0.25,1$ and $2 \%)$. The results showed that the ethanol extract of steam bark of Cynometra ramiflora Linn has potential as an antibacterial activity with $\mathrm{MBC}$ value of $2 \%$ against $S$. aureus, $P$. aeruginosa and $S$. sonei. On the other hand, K pneumonia and E. coli exhibited low potential because until highest concentration.

Keywords: Antibacterial, multi resistant, solid dilution, minimum bacterisid consentration (MBC). 